\title{
Terrors of Conscience: \\ Thomas Nashe and the Interiorization of Presence*
}

\author{
MAURICIO MARTINEZ \\ University of Guelph
}

Cet article se concentre sur une caractéristique principale du protestantisme populaire de Thomas Nashe : une attention sur les espaces intérieurs de l'armoire et de la chambre à coucher en tant que lieu privilégié de la réforme spirituelle de l'individu et de la communauté, à travers les mécanismes de la conscience qui troublent le chrétien au milieu de la nuit. Pierce Penniless, Christ's Tears, et The Terrors of the Night sont considérés comme un seul projet englobant correspondant à une méditation approfondie sur les manifestations du péché et du jugement dans le spectre spatial allant de la nation et de la cité au repli intérieur dans le foyer et le soi. Nashe fait appel au goût avide des lecteurs anglais pour la théologie calviniste populaire, en empruntant sa terminologie de la conscience à Calvin et aux écrits très appréciés de dévotion populaire tels que John Norden and William Perkins. Tout en décrivant l'armoire et la chambre à coucher comme des espaces de peur, de désespoir, de mise en accusation et de poursuite devant le tribunal de Dieu, Nashe promeut néanmoins ces espaces privés en tant que sites privilégiés de la communion avec la présence divine. L'intériorisation de cette présence par Nashe peut donc s'observer comme une confiance grandissante par laquelle la théologie de la Réforme cherche à s'intégrer dans la conscience collective de l'Angleterre de la fin de la période élisabéthaine.

\footnotetext{
"the Conscience of the wicked is alwayes feareful"

-index entry for "Conscience," Geneva Bible (1560)
}

$\mathrm{T}$ homas Nashe's writings at times make his position on religion appear ambivalent or contradictory. It seems a reasonable judgment to make of a writer who was employed by the church against the Martinists; who could publish such a proselytizing work as Christ's Tears Over Jerusalem (1593) the margins of which are saturated with chapter-and-verse citations of 
scripture-and then a year later refer to the adventures of his picaresque hero in The Unfortunate Traveller (1594) as "Acts and Monuments," in irreverent allusion to Foxe's celebrated work of Protestant martyrology. ${ }^{1}$ As current scholarship is engaged in reexamining the literary value of Nashe's texts, conditioned as they are by their shapelessness, their tongue-in-cheek moralism, and their grotesquery, critics are slowly revising a traditional view that has categorized these works as aesthetic failures. ${ }^{2}$ Pushed further, such insights suggest that the diverse career of this religious polemicist, marginal dramatist, and sensationalist prose pamphleteer-with a penchant for the salacious mixing of the pious and the vulgar-was well suited to an age preoccupied with the development of a popular consensus surrounding the theology of the English Reformation. While writing ostensibly to entertain, perhaps to inform, and certainly to make a living, Nashe persistently echoed and effectively promoted a new theology of the self that offered a new understanding of the subject's link to both social world and divine power, and that embodied all the ambiguity of the Elizabethan Religious Settlement.

Contemporary criticism has yet to contend with Nashe's relationship to that most tempting and elusive object of inquiry in early modern studies, the relationship between space and subjectivity. It has become commonplace to observe how changes in domestic architecture in early modern Europe brought forth a new emphasis on private life, as new interior spaces provided the material preconditions for the development of a new subjectivity of the individual self. $^{3}$ The assertion of such a relationship, however, has even from its first instances been complex, and has since found itself continually complicated: first, in the admission that early modern interiors never offered the kind of complete privacy supposed by moderns; ${ }^{4}$ second, that some of the most private spaces available to early modern subjects were in fact outdoor spaces; ${ }^{5}$ and finally, as Christopher Pye has persuasively argued, modern subjectivity may very well have constituted itself out of the very opposite of interior space, namely, the vanishing point of the horizon in visual art. ${ }^{6}$ Nashe merits consideration in this debate precisely due to tendencies in his work to locate the subject in relation to the space it inhabits, and here his preoccupation with religious questions, particularly the theology of the conscience, acquires a decisive importance. From Calvin to popular Elizabethan devotional writers like John Norden and William Perkins, and finally to Thomas Nashe, the interior spaces of the closet and bedchamber occupy a privileged position in a theology of presence, as the 
conscience of the Christian is an ever-present source of disturbance, particularly at night. Nashe's very status as a popular writer is linked to his ability to adapt the literature of devotion and some of its key themes-the conscience as an experience of presence, judgment, confinement, imprisonment, restlessness, terror, and despair-into a lampooning critique of English society in the satirical mode.

Interiors and interiority occupy a much more prominent place in Nashe's writing than is generally acknowledged. The Terrors of the Night (1594), for instance, treats the objects of fear encountered in the bedchamber, which Nashe asserts are almost entirely of the subject's own making. For Nashe, the dreadfulness of the night arises much less from darkness or the supernatural, as conceived by popular superstition, than from the fact that in the night the devil "keepeth his audit on our sin-guilty consciences," such that our thoughts become "nothing but texts to condemn vs" (1:345). This statement is merely the most explicit articulation of a common theme of which The Terrors is merely a form of denouement. From the everyman jeremiad of Pierce Penniless (1592) to the prophetic warnings of Christ's Tears and, finally, the extemporal ephemera of The Terrors, a dynamic interplay between the social and interior self emphasizes a distinctly post-Reformation conception of the relationship between God and the subject, conveyed most directly through the language of the conscience. As Camille Slights observes, "in Renaissance England the individual and the collective intersect in the conscience," 7 and these three texts stand out within Nashe's oeuvre precisely for the way in which they articulate this intersection, locating admonition and judgment on a spatial axis, from the widest spaces of the nation and the city to the narrowest confines of affective experience. The spatial logic of Pierce Penniless, Christ's Tears, and The Terrors strongly suggests their coalescence in a unitary project, one that castigates subjects for their transgressions of the moral law, shows the workings of divine judgment in the destruction of the city, and illustrates their correlates in the interior spaces of everyday life.

Nashe's use of the term "conscience" carries with it all the instability characteristic of his writing. He can reference the conscience in devotional terms, and then remark how "the Fox can tell a faire tale, and couers all his knauerie vnder conscience" (1:226), implying, as had his mentor Robert Greene, a shift in meaning from "conscience" to "idle words," thus illustrating the depths of hypocrisy in his time. ${ }^{8}$ Nashe's invocations of the conscience, however, are indeed 
so thoroughly imbued with themes drawn from the popular Calvinism of the 1580 s and 1590s that they can easily be identified as a vernacular complement to what Debra Shuger calls "the internalization of presence" central to the English Reformation's "habits of thought." This study uses the term "interiorization of presence" to describe a process by which Nashe and popular devotional writers linked the subjective experience of the conscience to the interior spaces one inhabits in the night. The object of study is therefore twofold: first, to trace the meandering migration of key tropes related to the conscience from Calvin to late-Elizabethan popular print by way of Norden and Perkins; and second, to identify the distinctiveness of Pierce Penniless, Christ's Tears, and The Terrors in their extended focus on the relationship between space and the sinning subject, which appears nowhere else in the Nashean corpus.

The Terrors in particular has so far evaded the rehabilitative efforts that have reshaped the critical reception of works such as Christ's Tears and The Unfortunate Traveler.$^{10}$ While the short pamphlet counts as one of Nashe's most instantly readable texts, R. B. McKerrow described the work as having "so desultory a character that any attempt at analysis would be useless," suggesting its scant importance "either as regards Nashe's biography or the history of letters in his time." ${ }^{11}$ G. R. Hibbard echoes the sentiment, writing that "over-wrought description on the one hand, and mocking skepticism on the other, is the outstanding characteristic of the whole pamphlet and the real unifying factor in it," even if he admits that at its beginning The Terrors "is serious and even religious in tone." ${ }^{12}$ Not all investigations have drawn such pessimistic conclusions. C. G. Harlow, for instance, has found the work a useful entry point for an extensive inquiry into the dating, sources, and biographical context of Nashe's writing, particularly with respect to his influences, social circles, and relationship to the late-Elizabethan patronage system. ${ }^{13}$ But even biographically informed readings haven't always favoured the author: Charles Nicholl finds in The Terrors a conspicuous preoccupation with melancholy, reflecting a despondency afflicting both the writer and his patron, the former especially arising from negative experiences in London and serious psychological discomfort. ${ }^{14}$ Critical assessments remain focused on the text's haphazard organization, with Lorna Hutson's brief but relatively neutral analysis describing the work as conforming to the logic of the carnival, "an analogy for the animate chaos which preceded the creation of the world." ${ }^{15}$ Craig Koslofsky offers a promising reappraisal of The Terrors in his sweeping study of early modern representations of the night, 
locating Nashe alongside Marlowe, Shakespeare, and Swiss poet Johann Lavater for writing of the night in terms of "nocturnal temptation," leaving the subject vulnerable to corruption and $\sin .{ }^{16}$

This study shares in the recent interest in Nashe as deeply embedded within the development of the cheap print market of Tudor-Stuart England, dominated, as it was, by works largely devotional in nature. ${ }^{17}$ David Baker lists as one of Nashe's most significant achievements the creation of a "marketable prose that elicited and matched its readers' own complicated desires and hostilities"-on display, Baker argues, in the moralizing discourse of consumption in Pierce Penniless. ${ }^{18}$ In her reconsideration of Nashe's participation in the Marprelate Controversy, Jennifer Andersen astutely points to the work of Alexandra Walsham and Peter Lake, who, while reaching slightly divergent conclusions, have effectively demonstrated a more intimate relationship between popular pamphlets and Protestant entrenchment than has previously been appreciated. ${ }^{19}$ The present focus on Nashe's representations of the conscience reveals not only extensive borrowings from popular Calvinist or pseudo-Calvinist writing, but also suggests that these lines of inquiry can be merged: that the appeal of these pamphlets to Reformation ideas is, in fact, inextricably linked to their status as commercial literature. In reading Nashe alongside the "best" and "steady sellers," what emerges is a sense of the depth to which interiorized presence had permeated some of the most popular works of his day. This may point to Brian Cummings's analysis of the way in which the doctrinal character of "Calvinist England," as he describes it, "lies not in its precise formulation, nor in its pseudo-psychological effects, but in the way that it saturates the discourse of the culture beyond the understanding of its speakers"; $;{ }^{20}$ or it may suggest that Nashe was aware that vernacular Calvinism was precisely what the market demanded, and that he was all too happy to supply. Either way, Nashe's writing displays one avenue by which theological principle becomes popular understanding: a process based not in uniform adherence to orthodox positions, but rather in the adoption of a language of the self linked to a post-Reformation landscape of sin and judgment. Nashe's significance in this regard lies precisely in how the symbols, images, and themes surrounding the conscience, ever present in the work of popular Calvinists, are rigorously mobilized in the texture of Nashe's own writing.

To isolate implicit Calvinism as a unifying element in Pierce Penniless, Christ's Tears, and The Terrors is to find a thread of consistency within a context 
of stylistic, and indeed theological, inconsistency. Recurrent gestures to the Catholic doctrine of good works permeate these texts and are crucial to their satirical edge. The bulk of Pierce Penniless features satirical descriptions of the frequent misdeeds of various social and national groups, structured as an elaboration of the Seven Deadly Sins. This latter Catholic motif, combined with the tract's extensive demonological expositions, makes it very difficult to classify Pierce Penniless as emblematic of an orthodox form of post-Reformation belief. In Christ's Tears, Nashe lingers on the necessity of "good deeds," which he describes as "a tribute which we pay vnto God for defending vs from al our ghostly enemies, \& planting his peace in our consciences," while adding, in a marginal note, "it is not my meaning in all this discourse of good deeds to seioyne any of them from Fayth" $(2: 83,104 n)$. In other words, the focus on works was so pervasive in these pamphlets that Nashe felt the need to insert qualifications so as to not distort their Protestant theological message. Nashe's repeated gestures to the old religion show him to be familiar with the "reluctant and partial conformity" that Eamon Duffy describes in his surveys of lingering Catholic sentiment in post-Reformation England. ${ }^{21}$ On the other side of the Tudor religious spectrum, a short stint in the patronage of Archbishop John Whitgift exposed Nashe to a "moderate" Calvinism that adopted its theology while waging cultural and physical warfare against Puritan demands for ecclesiastical reform..$^{22}$ Such a middling or even conflicted theological road upon which Nashe's writing travels appears a product of an England populated by "church papists," "parish Anglicans," and other believers who for a variety of reasons sought a confessional identity ambiguously conformist, refusing the commitments of treasonous Catholicism on the one hand, and subversive Puritanism on the other. ${ }^{23}$

\section{The conscience as a habit of mind}

When positing a "Calvinist" conception of the conscience, it is important to lay less stress on theological innovation, and more on newfound significance. As Slights observes, the essential theological principles of the conscience articulated in late-Elizabethan England differ little from the interiority of Augustine and its elaborations in the writings of the Scholastics. ${ }^{24}$ While Calvin references the conscience in virtually all of his doctrinal writings, only in Institution of 
the Christian Religion (1559, English translation 1561, reprinted 1587) does he actually lay out his definition with its distinctively theological approach. ${ }^{25}$ And on more than one occasion in the Institution, Calvin explicitly relates the torments of conscience with sleep and the night. Calvin suggests that reprobates are cursed by a perpetual state of wakefulness, unable to sleep due to the terrible visions and dreams that plague their inward minds. "The rest which they haue," Calvin writes, "if they haue any at all, from torment of conscience, is much like to the sleepe of drunkards or frantike men, which euen while they sleepe doe not quietly rest, because they are at euery moment vexed with horrible \& dreadful dreames." ${ }^{26}$ Calvin later writes, "our conscience doeth not suffer vs to sleepe a perpetuall sleepe without feeling, but that it inwardly is a witnesse and admonisher of those things that wee owe to God." ${ }^{27}$ Calvin defines the term in part through reference to its etymology, in part through reference to the writings of St. Paul:

as when men do with minde and vnderstanding conceiue the knowledge of thinges, they are thereby saide to knowe, whereupon also is deriued the name of Science: Knowledge: so whey they haue a feeling of the iudgement of God, as a witnesse ioyned with them...that same feeling is called Conscience. For it is a certaine meane between God and man, because it suffereth not man to suppresse in him selfe yt which hee knoweth but pursueth him to so farre til it bring him to guiltines. This is it which Paul meaneth, where he saith that conscience doth together witnes with men, when their thoughts do accuse or acquite them in the iudgement of God. A simple knowledge might remaine as enclosed within man. Therefore this feling which presenteth man to the iudgement of God, is as it were a keeper ioyned to man, to marke and espie all his secrets, that nothing may remaine buried in darknesse. Whereupon also commeth that olde Prouerbe, Conscience is a thousande witnesses. And for the same reason Peter hath set the examination of a good conscience for quietnesse of mind, when being persweded of the grace of Christ, wee doe without feare present our selues before God. ${ }^{28}$

These passages contain an inventory of images and themes that would later be developed by Elizabethan writers who sought to associate the conscience with restlessness, sleeplessness, financial accounting, and the legal language of 
judgment. First, the ensuing discourse will continually reaffirm the conscience as a matrix that combines knowledge and affect, mind and body. Second, the theme of restlessness and weariness will develop into an explicit allusion to a particularly Calvinist interpretation of the story of Cain, a trope for the crime committed in secret to which only God bears witness. Like condemned criminals, the subjects of such a discourse are relentlessly pursued as long as necessary to bring them to justice, with the interior self functioning in the role of a "keeper," the role refused by Cain in the slaying of his brother. It is likely that the editors of the Geneva Bible had precisely such an understanding in mind in glossing the story of the first murderer. The marginal note to Genesis 4:7 states explicitly that "sinne shal stil torment thy conscience," the effects of which are implied by the curse of Cain in Genesis 4:12: "a vegabonde and rennegate shalt thou be in the earth," with another marginal note adding, "thou shalt neuer have rest: for thine heart shal be in continual feare \& care." 29 The conscience is presented here as both a signal and a mechanism of divine judgment, an external force of arraignment and prosecution linked to the inner world of thought and emotion. And this inner knowledge will in turn have its effects on the body, manifested in unrelenting fear, sleeplessness, and fatigue.

Calvin describes affliction and remedy in one and the same movement, and both allude to the scene of writing and the uses of literacy. He suggests that sins are "marked," with implications both for the conscience and the act of examination that aims to allay the fears associated with its functioning. Calvin implies that what is to be inspected or questioned within the interior mind is not merely observational but ultimately textual evidence, with a kind of reading empowering the individual in confronting the most fearful aspects of divine judgment. Citing John Chrysostom, Calvin designates the night as a special time where the examination of the conscience is meant to take place, in turn associating this examination with the interior space of the bedchamber. "Confesse thy sins vpon thy bed," Calvin writes, "that there thy conscience may dailie recognise her euils. Againe: But now it is not necessary to confesse when witnesses be present, let the examination of thy sinnes be done with thy thought." ${ }^{30}$ Knowledge, judgment, the body, and interior space-these images would be taken up and expanded upon by writers in subsequent decades, in some of the most popular printed texts of Nashe's time.

Calvin was one of the most widely read authors of sixteenth- and early seventeenth-century England, and the Institution a landmark text in the 
Calvinist canon. ${ }^{31}$ The influence of Calvin on English writers, particularly devotional writers, was profound. As Ian Green notes, especially "in the last two decades of the sixteenth century, we find a number of treatises being published on the inner life of faith which have a clear Calvinist character." ${ }^{\prime 2}$ John Norden's Pensive Man's Practice merits inclusion in such a list, if only for its faithfulness to Calvin's language of the conscience and its associated imagery of wakefulness and fear. This widely popular prayer book was undoubtedly influential in popularizing moderate Calvinist conceptions of personal piety, including an intense preoccupation with the night, going through more than 40 editions by 1627. ${ }^{33}$ The frontispiece cites two biblical passages pointing to the schedule and purpose of prayer: Psalm 55, "in the euening and morning, and at noone day, I will call vpon the name of the Lorde, and that instantly, and he will heare mee," and James 5:13, "if any be afflicted, let him pray." ${ }^{34}$ Norden's prayers locate the evening and the night as particularly significant-even prayers to be said in the morning include thanks offered to God for sleep and protection the night before. The "morning prayer for the working day" offers a brief consideration on the rewards of a peaceful night: "what a great benefit we receiue at the handes of almightie God, by our naturall sleepe, none is ignoraunt what perrils wee escape, in the darke \& dolefull night, wee may easilie judge." ${ }^{35}$ The inherent fearfulness felt in the night, for Norden, is coupled with a sense of God's intimate control over the natural world. "Natural sleepe" is a benefit derived from God, to counter the inherent melancholy of darkness.

For Norden, the notion of the conscience as a witness is best expressed in its ability to "espie" upon secret sins, upon the actions, thoughts, and offences committed by individuals, even while dreaming. The "prayer for the working day" asks God to forgive "my wickednes, mine offences, and sinne committed, either this night past, by foolish dreames, fantasies, or other temptations, or at any time since I came into this miserable worlde," while the "prayer for Sunday morning" asks forgiveness for "what soeuer I haue committed, and doone against thy diuine will, eyther sleeping or waking, this night or anie time (secretlie or openlie) heeretofore, by reason of the corruption which remaineth in me." ${ }^{37}$ The theme of judgment reaches its climax in the prayer for the "sorrowful sinner," one whose confrontation with the conscience has led to an uncontrollable fear and despair. The prayer includes practical advice for effective self-examination, one that begins with the need to "acknowledge our selues to bee wretched sinners" and "with feare fall downe before the mercies 
seate of the highest iudge. Contemning our selues to be most vnrighteous and iustly deseruing confusion"; such "afflictions" of conscience arise from the subject's very admission that one "haste beene a notorious offender." ${ }^{38}$ The prayer's melancholic tone is offered as a necessary correlate to the experience of moral transgression and heavenly prosecution, linking the fear of judgment with the despair of reprobation.

As Norden delves deeper into the afflictions associated with self-examination, the focus on fear begins to constitute one of the text's most defining features. The prayers code this fear in the language of the body, expanding on Calvin's language of weariness and its attendant associations with the curse of Cain as eternal wandering:

Lord I bewayle mine heinous offences, and am moste sorye for my sins, which are so vile, \& the burden of them so intolerable, that when I turne mine eyes but to the beholding of them farre off, I am by and by, stryken with so great dreade that I am driuen to the most heauie sighes, greeuous groanes, and thinke my life an enemie vnto mee, wishing the beginning of my dayes, had been the day of my departure out of this miserable worlde. But (moste sweete Lorde) when I note them perfectlie in my minde, \& take as it were a straight account, what the deeds of my youth have beene, (beeing indeede) most lewde, most euill, most vile, and sinfull, what a terror doo I suffer in minde? what a dungion of dollours, doth open it selfe (as it were) to swallowe mee vp? what gryping greefes doo torment my poore conscience in so much as I am at the pittes brinke, of dispayre, wauering in minde to and fro, seeking rest, but loe (Lorde) vnquietnes of minde, oppresseth me so sore, that considering my selfe, what I haue beene, and what I am, a greate matter vexeth me. ${ }^{39}$

The prayer recalls Calvin's focus on the conscience as a combination of knowledge and affect, with Norden expanding on this relationship with sensationalist prose. Knowledge, for Norden, is a product of optics and of reading: the eyes turn inward; sins are beheld, noted, then taken as a "straight account," which echoes Calvin's description of sin as things owed to God. The ensuing description of the terrors suffered in the inward mind as a result of this visual and textual apprehension of reprobation evokes various forms of criminal punishment. The preternatural image of a dungeon that opens itself to swallow the subject, 
bringing it to the "pittes brinke," moves quickly to an account of "wavering," a kind of twin portrait of confinement and openness that shows the inability of the subject to settle comfortably in the interior space in which it cannot help but reside. Norden adapts this Calvinist framework for understanding the conscience by dramatizing the experience and its effects, adapting theology to the language of lived experience.

Perkins, like Norden, expands the inventory of images associated with the conscience while maintaining the broad theological outlines elucidated by Calvin. Perkins's writings recall Calvin's focus on the conscience as a point of mediation between the human and the divine, knowledge and affect, visual apprehension of sin and the visceral experience of confinement and fear. What distinguishes Perkins is a marked emphasis on the doctrine of predestination, and the differential experience of the conscience for the elect and for the damned, a more conspicuously Calvinist stance befitting the Cambridge divine's status as a so-called moderate Puritan. ${ }^{40}$ His Treatise Tending Unto a Declaration Whether a Man Be In the Estate of Damnation or in the Estate of Grace (1588) is a formal and carefully argued treatise exploring one of the central questions confronting Calvinist believers: How might they know and discover their election? While not one of Perkins's most popular works, it nonetheless appeared in at least nine separate editions from 1588 to $1619 .{ }^{41}$ Within Perkins's predestinarian framework, self-examination becomes the principal method by which such a determination can take place, and his work becomes "a guide to aid men in searching their souls to discouer their standing in the eyes of God." 42 His account of this process nonetheless parallels Norden's in an expanded language of guilt that ascribes to the conscience both an edifying and terrifying quality.

Perkins, for instance, enthusiastically appropriates the stern portrayals of divine judgment so important to both Calvin and Norden. He writes, "all men naturallie haue corrupt and defiled consciences, accusing them \& arraigning them before Gods iudgement for their sinnes," but adds that "the knowledge which the reprobate hath...is onelie a generall \& confused knowledge: but the knowledge of the elect, is pure, certaine, sure, distinct, and particular: for it is ioined with a feeling and inwarde experience of the thing knowne." 43 True interiority, Perkins suggests, is only available to the elect, as it requires a relationship between knowledge and affect particular to them alone. Damnation or Grace, like Pensive Man's Practice, also privileges the apprehension of secret sins as a sign of a confrontation with presence, the ultimate divine witness. Perkins 
frames this through an exhortation to the pious to be inherently suspicious of their secret sins. "If so be it," Perkins declares, "that after examination, a man cannot finde out his sinnes (as no man shall finde out all his sinnes, for the heart of man is a vast gulf of sinne, without either bottome or banke, and hath infinite hidden corruptions in it) then hee must in godly iealousie, suspect himself of his vnknowen sinnes." ${ }^{44}$ In contrast to Norden's sorrowful sinner, whose ability to visualize his guilt brings him astride a pit of despair, Perkins presents the heart itself as the very gulf such sinners cannot help but avoid, encouraging them to assume their sin even if it is not immediately visible to the inward mind. Such an investigation into precisely this inherent guilt within oneself brings with it a new knowledge, and a new fear: "when the spirit hath made a man see his sins," Perkins writes, "he seeth further the curse of the law ... his heart is smitten with feare and trembling, through the consideration of his hellish and damnable estate." ${ }^{45} \mathrm{He}$ presses the point even further: "the reprobate hath oftentimes feare and terror of conscience ... because he considereth the wrath and vengeance of God, which is most terrible"; Norden uses similar terms when he writes that "loosing the favor" of God "drives vs into a greate feare and terrour, procuring a greate dislike and lothing of our selves." ${ }^{\prime 6}$ While Perkins more strongly asserts the inherent cleavage between the experience of the elect and the damned, the similarity in their rhetoric nonetheless suggests a reliance on a common stock of images and themes that make self-examination an inherently terrifying act.

The mutually constitutive links between Calvinist theology on the one hand and discourses of popular piety on the other come closer to the fore in Perkins's shared interest in the effect of the conscience on bodily processes of sleep and dreaming. That both sleeplessness and dreaming present themselves as involuntary relates directly to the involuntary nature of sin, election, and damnation. Presence emerges as that which confines the mind to thoughts of its own state of involuntary transgression. As the elect are more inherently attuned to the manifestations of presence, they are more susceptible to "outward afflictions," which in turn provoke disturbances in sleep. The sinning subject, Perkins argues, will find that "his old sinnes wil come a fresh into his remembrance, and trouble him. Hee is sleepie, and in his sleepe he hath visions, and dreames and anxietie of spirit," and even the wicked, endowed with an "evill conscience," while unable to consider properly the implications of the curse of the law, and to recognize their inherent condemnation in the eyes of God, are still "brought into feareful terrors, and often draw neere to desperation." ${ }^{47}$ 
Even in the voice of a "perfect Christian," Perkins suggests that the conscience provokes unexpected and involuntary disruptions of bodily rest:

I went with a quiet conscience (mee thought) to my bedde, and then I slept soundlie till three of the clocke in the morning, but I dreamed that one came to carrie me to pryson, vpon that on a sudden I awaked and beeing afraide looked about mee and fell to consider why I should be afraide, and I remembered that I had sinned against God ... o then my feare increased, and I thought that hell gaped to deuoure me, and the law looked vpon me with such a terrible countenance, and so thundred in mine eares, that I durst not abide in my bed, but vp \& to goe. ${ }^{48}$

The episode dramatizes the relationship between human knowledge and divine presence that again bears a striking resemblance to both the popularizing method and the imagery of Norden's prayer book. Perkins suggests the limitations of knowledge by showing how dreaming forces a confrontation with a conscience that is elusive, evasive, and must be perennially hunted. Recognition that the scene is set in an interior space, that it includes the consideration of knowledge and feeling manifesting themselves in the interior self, and that the dream of imprisonment is interpreted as indicative of transgressions of the moral law, forms a key to the imagery of the conscience in Nashe's 1592-94 works, particularly Christ's Tears and The Terrors. Calvin, Norden, and Perkins provided a fertile ground from which Nashe could construct his own language of the conscience, combining this vernacular interiorization of presence with other discourses drawn from biblical prophecy and popular superstition.

\section{From public to private culpability}

Pierce Penniless, Christ's Tears, and The Terrors continually oscillate between admonitions of sin that pervade the social fabric and retrospectives on the experience of guilt as manifested in the conscience. The prologue to Pierce Penniless hints at the public nature of the work, as the title character begins his search for the devil first among the lawyers of Westminster Hall and then among the merchants of the Royal Exchange. It is at the latter that he finds the Knight of the Post, who will deliver the writer's "supplication" to the devil, 
essentially an enumeration of individuals and groups who "deserue no longer to liue (as men) amongst men, but to bee incorporated in the society of diuels" $(1: 165) .{ }^{49}$ Only rarely in the pamphlet does Nashe make any significant reference to the life of the inner self, focusing instead on sin as it manifests itself in outward appearances and social relationships. Pierce Penniless, for instance, describes in detail how "Greedines" and his wife, "Dame Nigardize," leave even the rats and insects that inhabit their home wanting, how upstarts and the prideful show their vanity in dress and speech, and how the Irish, Spaniards, French, Danes, and others show their various faults in actions and words. This "hodgepodge of narrative, theology, denunciation, and social commentary," as Baker describes it, ${ }^{50}$ appears so ambitious in its itemizing of transgressions in the totality of the social field that any exploration of interiority would seem hopelessly out of place.

The notable exceptions to this rule attest to the fact that, even while Nashe disparages "dul-headed Diuines" who "preach pure Caluin" (1:192), he readily adopts the language of popular Calvinism when it comes to his portrayal of inwardness and self-examination. In the prologue to Pierce Penniless, the title character describes his extreme poverty in the form of verse. The first stanza begins, "Why ist damnation to despaire and die, / When life is my true happinesse disease," and ends with a direct appeal to the torments of conscience: "Diuines and dying men may talke of hell, / But in my heart, her seueral tormentes dwell" (1:157). Nashe also narrates an episode that illustrates the redemptive powers of self-examination. It concerns a story of "Countie Molines (sometime the Prince of Parmaes Companion)" and his "altered course of life," which was brought into a state of repentance through the powers of his own conscience:

Vpon a day entering into a deepe melancholy by himself, [Molines] fell into a discoursiue consideration what this world was, how vaine and transitory the pleasure thereof, and how manie times he had offended God by surfetting, gluttony, drunkennes, pride, whoredome, and such like, and how hard it was for him that liu'd in that prosperitie that he did, not to bee entangled with those pleasures: whereupon he presently resolu'd, twixt God and his owne conscience, to forsake it and al his allurements, and betake him to the seuerest forme of life vsed in their state. (1:203) 
Nashe appears to privilege knowledge over feeling here, presenting the count as a would-be philosopher who, by entering into an internal dialogue over the nature of the life he was leading, decides to change its course. He takes to a life of humility and poverty, but as Nashe relates, "what a notable rebuke were his honourable Lowlines to succeeding pride, if this prostrate spirit of his were not the seruaunt of Superstition; or hee mispent not his good workes on a wrong Faith" (1:204). This assertion of the necessity of the sola fide principle of Reformation theology functions as a mechanism to articulate a playful irony, by which the count remains damned in spite of the very transformation the narrative took such pains to illustrate. But the general contours of the experience of self-examination remain roughly those we find expressed in Norden and Perkins: provoked by a melancholy feeling, in solitude, the count approaches a full recognition of his status with respect to the moral law, and the resolve that results from this recognition is located in a medial position between the subject and the divine. That the conscience is figured as internal revelation inspired by the external force of presence conforms to the discourse actively being built by writers who, in turn, are building on Calvin's rhetorical legacy.

Pierce Penniless appears to nod, or at least run parallel, to the work of Norden and Perkins in other ways, gesturing to the doctrine of predestination and the theme of criminality through a digression into theodicy. The narrator urges "senior Belzibub" to claim his "predestinate children, not only that they haue a father, but that you are he that must owne them," while also referring to the devil as a "furnace," by whom "the Elect are tried, who are vessels of wrath and saluation" (1:172, 235-36). The latter point recalls Perkins's fictional Christian, who calls his afflictions of conscience "liuelie testimonies of my saluation. ${ }^{51}$ In response to a question as to whether devils hurt individuals by their own power, or by a power granted to them by God, the Knight of the Post replies, "they can not hurt but permissiuelie, or by some speciall dispensation":

as when a man is faln is into the state of an out-law, the Law dispenseth with them that kill him, \& the Prince excludes him from the protection of a subject, so, when a man is a relaps from GOD and his Lawes, God withdrawes his prouidence from watching ouer him, and authoriseth the devil, as his instrument, to assault him and torment him, so that whatsoeuer he dooth, is Limitata potestate, as one saith; insomuche as 
a haire cannot fall form our heades, without the will of our heauenlie Father. (1:236)

The passage forms a significant gloss to the legalistic language of divine judgment employed by Calvin and his English emulators; indeed, in Christ's Tears Nashe will continue to figure transgressions of the moral law within the framework of outlawry. But this passage is also of preeminent thematic relevance to the pamphlet as a whole, emphasizing its bitter irony. As stated in the preamble to the "supplication," while the writer entreats the devil for an "encrease of damnation, and malediction eternall" for the detailed catalog of sinners he castigates (1:165), for the devil to unleash his torments the command must come ultimately from God. The writer has been supplicating, as it were, in all the wrong places.

Pierce will find the answers to his entreaties not in sixteenth-century London but in first-century Jerusalem. The Jerusalem of Christ's Tears is an outlaw city, condemned by God and abandoned to its enemies. Citing the Psalms, Nashe describes a time in which "the Lord is knowne by executing judgment," and suggests that the sinning London of Pierce Penniless "harken counsaile of her great Grand-mother, Ierusalem" (2:15). As Catherine Cox explains, Nashe assumes the role of a "lay preacher," whose mode is that of the "apocalyptic grotesque," and whose stated purpose is "to utter some-thing that may mooue secure England to true sorrow and contrition." ${ }^{2}$ By stating his purpose as that of affecting a kind of melancholy on his readers, Nashe shows an intention to function not only as a lay minister instructing the godly toward repentance, but also as a conscience, bearing witness to both the destruction of Jerusalem and the sins of London. This impulse is corroborated by the prose tragedy's numerous appropriations and adaptations of the Calvinist discourse of the conscience, with all its attendant imagery of sleeplessness, dreams, judgment, and confinement, framed within the legalistic language of outlawry as invoked in Pierce Penniless.

References to sleeplessness, restlessness, and dreaming appear peripheral to the central narrative of Christ's Tears, yet permeate the text as manifestations of the overarching theme of divine judgment. Nashe writes of the prognosticating warnings that appear to the inhabitants of the city, noting the "many \& sundry waies GOD spake by Visions, Dreames, and Prophecies, and Wonders...onely to moue his chosen Ierusalem wholie to cleaue unto him" 
$(2: 16)$. Addressing the citizens of Jerusalem in the voice of Jesus, Nashe points to the failure of these dreams and visions to provoke appropriate feelings of repentance and recognition: "thou hast no sting or remorse of conscience; thy soule is cast in a dead-sleep, and may not be awaked though Heaven \& Earth should tumble together" $(2: 37) .{ }^{53}$ Nashe then relates the impending catastrophe of invasion to both the Genesis account of the Great Flood and Jesus's miracle of walking on water, depicting the conscience as a ship floundering on troubled waters. "As a guilty conscience can no where take rest," Nashe writes, "so no more can they in the Sea"; Jesus was "borne to suppresse \& treade down sinne under foote, in the night time (when that sinne-inhabited element is wont to be most lunaticke) walke on the crests of the surges as on the dry land" (2:38). Nashe uses the allusion as a metaphor for the edifying possibilities of the conscience, inserting a reference to the nighttime and its penchant for "lunatick" fears and perturbations. He develops the association between sin and the night further in a passage that explicitly refers to the process of self-examination. Nashe explains, "sinne takes no rest but on earth, and on earth no rest in the night, but the day," and since God hides "all other obiects from man's sight in the night, that then he should have no occasion to gaze elsewhere, but full leysure to looke into himselfe. In which regard, least he shold looke into himselfe, and so repent, hee will not let him see with his owne eyes, but lendeth hym other eyes of despayre or security to see withall" (2:39). Nashe refers to a kind of a willed intrusion of presence into the interior self in the form of "other eyes" that are lent to the subject should they choose to bend themselves towards introspection and repentance. Christ's Tears places greater emphasis on the conscience than Pierce Penniless, expressing an interest in its mediating function between the subject and divine power. As the narrative continues, the interior self becomes more associated with the architecture of the city and its interior spaces.

Nashe's Jesus equates the protection afforded to the pious in sleep to the protection of the city from foreign invasion. He relates that Jerusalem should have courted his protection in the night, comparing himself to a hen that "watcheth" for his chickens "whiles they sleepe," while extending that protection to the maintenance of the city itself: "I would haue sette an Angell (with a fiery-sword) in your gate," as his vigilance "shoulde haue sentineld for all your sleepes" (2:43). The connection between the well-being of the city and that of the individual conscience becomes more pronounced as Nashe moves 
closer into the interior spaces of the city, where divine abandonment-as in the abandonment of the outlaw-is most acutely felt. Nashe's Christ urges the city: "discende into the close of thyne owne conscience, and enquire how oft I haue come thither and cald upon thee to gather thee. Examine they hart \& thy reynes if I haue not secretly communed with thee by night"; this "close" becomes the premier site for the faithful subject to gather itself, to "enter into meditation of [its] lamentable estate" (2:55). The statement does more than recall Perkins's perfect Christian, who awakes from his dream with full knowledge of his "damnable estate," in that the object of such a gathering is less the pious individual than the city as a whole. Christ's injunction, for the city to enclose itself in the innermost depths of its interior self/selves, mirrors the "melancholy Owle," symbol of the desolation of the city, in its movement from the housetops of Jerusalem into the Holy of Holies: in the Sanctum Sanctorum, the owl, amid violent slaughter "in the Temple-porche," builds its nest $(2: 58,61)$. This movement from exterior to interior space intensifies as Nashe turns from Jerusalem to London, where he downplays the threat of external forces and foregrounds the torments of conscience.

As Christ's Tears turns its attention to the spiritual reform of its English readers, what emerges approximates an addendum to Pierce Penniless, with the itemizing of public crimes in the latter being glossed by the inward effects on their perpetrators. Nashe defines these interior torments as a "death that growes inward" (2:83). Referring specifically to London's recent plague, to which, as Cox suggests, Christ's Tears is a direct response, Nashe asserts that, in the efforts to stem the spread of disease, "we purge our houses, our bodies, and our streets, and look to all but our own soules" (2:160). ${ }^{54}$ In a reaffirmation of an authorial stance in which Nashe would act as the conscience of the city, he stresses the importance of knowledge in the path toward repentance, within an organization of space that, like judgment itself, "grows inward." Nashe contends that, if the citizens of London were able fully to comprehend "the quietest corner of hel ... transported into a vision but of three minutes," then "we would have it painted in our Gardens, our banquetting-houses, on our gates, in our Galleries, our Closets, our bed-chambers" (2:170). This movement from outside to inside, from garden to bedchamber, parallels a shift in focus from the public admonitions of Pierce Penniless to the interiorizing reprimands of Christ's Tears, a movement that would reach its completion in The Terrors. 
Thus it appears an almost teleological necessity, from the theodicy of Pierce Penniless to the "death that grows inward" of Christ's Tears, for Nashe to write subsequently that "the terrors of the night ... are as many as our sinnes" (1:345). In The Terrors, Nashe assertively connects the fear of the dark not with ghosts and other supernatural beings, but rather with the torments of conscience, figuring the bedchamber as a prison-like space in which we are brought to trial and confronted with our transgressions of the moral law. ${ }^{55}$ The Terrors connects the imagery of confinement with an explicit allusion to the scene of writing, as the night is

the Diuells Blacke booke, wherein hee recordeth all our transgressions. Even as when a condemned man is put into a darke dungeon, secluded from all comfort of light or companie, he doth nothing but dispairfully call to minde his gracelesse former life, and the brutish outrages and misdemeanours that have throwne him into that desolate horrour; so when Night in her rustie dungeon hath imprisoned our ey-sight, and that we are shut separatly in our chambers from resort, the diuell keepeth his audit in our sin-guilty consciences, no sense but surrenders to our memorie a true bill of parcels of his detestable impieties. The table of our hart is turned to an index of iniquities, and all our thoughts are nothing but texts to condemne vs. (1:345)

Nashe displays his characteristic fondness for words associated with the act of writing, but also manages effectively to summarize the disparate themes and images associated with the conscience in the works of Calvin, Norden, and Perkins. Nashe appropriates the language of despair, criminal transgression, and imprisonment, as well as the conception of sin as something visualized in its entirety, as a list or "bill of parcels" rendering a full account of one's standing with respect to the law. Norden's "dungion of dollours" and Perkins's dream of imprisonment, and furthermore the implication of a perfect knowledge of judgment, all call to mind a Calvinist discourse in ways that similarly evoke the "desolate horrour" of the destruction of Jerusalem. But The Terrors makes clear that the "chamber" relates directly to the "dungeon" of reprobation, and that these are relatable through the experience of judgment, which is above all else the intrusion of divine presence into the recesses of the inward mind. 
Indeed, as Nashe continues his description of the horrors that envelop the subject in the night, he continually deploys and adapts motifs drawn from his invocations of the conscience in Christ's Tears. He once again draws upon birds in comparing the night and day to the raven and the dove of the Noah story. Nashe figures the day as the dove that, when sent out to search for land, "returneth to our eyes with an Olive branche of peace in his mouth"; the raven, on the other hand, "neuer commeth back to bring anie good tidings of tranquilitie: a continuall messenger hee is of dole and misfortune" (1:346). Birds of warning, which appeared on the rooftops of the condemned city of Jerusalem, return in The Terrors, as God uses both birds and the devil to signal and execute his judgment of the sinner. Nashe uses birds and bird-catching as an analogy for the strategies the devil employs to torment sinners; the devil comes "in the name of sin, as Gods executioner," and like those who trap birds by imitating their voices, so will the devil "imitate the voices of Gods vengeance, to bring vs like birds into the net of eternall damnation" (1:348). Later, Nashe returns to the motif of the "melancholy Owle" who sets up its nest in the ruins of the Second Temple, stating that, for traitors, the night "shalbe as a night owle, to vexe and torment you" (1:385). Just as the very mobility of birds allowed for their deployment in Christ's Tears as figures that exemplify the totality of divine judgment, from globus to locus, their inclusion in The Terrors as analogies signifies not only a unity of theme between the two works, but also the inextricable link between external sign and interior perception.

Weariness is another important theme in The Terrors that points to the intimate connection between Nashe's writing and popular Calvinist conceptions of the conscience. When Nashe compares "rest we take in our beds" to the rest "the warie traveler taketh in the coole soft grasse in summer" (1:345), he reproduces the discourse of fatigue and vagabondage derived from the Calvinist interpretation of Cain. When explaining why the devil is said to lurk in churchyards and "places where men are buried," Nashe asserts that the devil "delights in nothing so much as to be vncessantly raking in his treasurie," and thus rakes among the bodies of the dead to give the living the impression that "after death their bones should take no rest" (1:349). ${ }^{56}$ Taken together, the inference that our own rest is endured with the weariness of a traveller, and that the devil is seen as disturbing the rest of the deceased, connects the external manifestations of divine will with the affective experience of it in our innermost selves. Nashe points to the story of Tullus Hostilius, "who tooke vpon him to coniure vp Jove 
by Numa Pomillus bookes," and yet still "had no sense to quake \& tremble at the wagging and shaking of euery leafe, but that he thought all leaues are full of wormes, and those wormes are wicked spirits" (1:350). While Harlow points to Henry Howard's Defensative Against the Poison of Supposed Prophecies as a likely source for this passage, the texture of Nashe's telling bears a conspicuous resemblance to an account of fearfulness in Calvin's Institution. In Calvin, the figure is not Hostilius but Caligula:

none more miserably trembled when any token of Gods wrath appeared. And so against his will he quaked for feare of him whom of willful purpose he endeuoured to despise. And the same may a man commonly see to happen to such as he was. For the bolder despiser of God that any man is, the more is hee troubled at the very noyse of the falling of a leafe. ${ }^{57}$

In Howard's Defensative, "some to atchive theyr eager wish...figure out a certaine feare before theyr eyes, and worshippe it: with Hostilius the Romaine, shrincking in a seruile manner, at the falling of the smallest leafe." ${ }^{58}$ The texture of Howard's account closely resembles Calvin's description, yet Nashe's expansion better preserves the relationship between will and weakness that colours the narrative of Caligula. While Howard's Hostilius worships the very fear that troubles him, in Nashe's account he quakes and trembles in spite of his desire, and will, to conjure pagan gods. Nashe's Hostilius exemplifies the kind of fear described by Perkins, which finds the subject notwithstanding its attempts to quell those fears either with piety or intransigence. For Nashe, Hostilius is by far not the only one to quake and tremble in fear provoked by supernatural presence; rather, Nashe repeats Calvin in using the Roman as an exemplum for a generalized condition, whereby "there is no man put to any torment, but quaketh \& trembleth a great while after the executioner hath withdrawn his hand from him. In the day time wee torment our thoughts and imaginations with sundry cares and devices, all the night time they quake and tremble after the terror of their late suffering" (1:355). This repetition (with variation) of the motif of quaking and trembling summons the style of Norden and Perkins, and further aligns Nashe with these popularizing writers. The Terrors continues their work by expanding, adapting, and submerging their terms, while attempting artfully to amplify their effects: God is compared less to a judge and more 
directly to an executioner, forcefully intensifying what it means to live under the curse of the law.

Thus it is possible to read Nashe's description of the nighttime as one in which our thoughts are "troubled \& vexed when they are retyred from labor to ease" in relation to a discourse of the conscience inaugurated by Calvin and enthusiastically adopted by English writers in his wake. While Calvin's sinners are "at euery moment vexed" with the torments of their dreams, for Norden, those who pray "in miserie and trouble" repeat Psalm 102:6, "I am like an Owle in the desert," and cry, "I can not enioye any liberty either of body or minde"; for the sinning subject, the experience of presence is that of being "stricken with greate sorrowe in minde, and vexed with intollerable greefe." ${ }^{59}$ In the work of Perkins, the reprobate "is often vexed within himself", and even the elect that are brought to despair by the workings of their own consciences can heed "the example of David: who by all coniectures was least troubled with Melancholie, and yet neuer any tasted more deeplie of the sorrow and feeling of Gods anger for sinne than hee did, as the booke of Psalmes declareth." ${ }^{60}$ The Terrors goes further than Pierce Penniless and Christ's Tears in highlighting this connection by foregrounding the effects of human trespasses in interior spaces and in subjective experience, as opposed to illustrating their manifestations in the social life of city and community.

The Terrors breaks with these other pamphlets in its presentation of the solitary individual without seeking to qualify that individual as a member of a social or national group. Nashe writes, "Ah woe be to the solitarie man that hath his sinnes continually about him, that hath no withdrawing place from the diuell and his temptations," for "dreames to none are so fearfull, as to those whose accusing private guilt expect mischiefe euerie hower for their merit" (1:357-58). He later adds, "a solitarie man in his bed, is like a poore bed-red lazer lying by the high way side," whose wandering thoughts add to the "secret smarting paine he hath alreadie... a further sting of impatience, and new lanch his sleeping greefes and vexations" (1:376). By laying stress on the solitary individual, Nashe creates in The Terrors an inverse image of the social world presented in Pierce Penniless and Christ's Tears. And while, in concluding the tract, he lashes out at old targets, like "pore mens children" whose social climbing manifests itself in sumptuous clothing, as well as usurers, adulterers, corrupt judges, and magistrates (1:384-85), his attack is really an addendum to a work that privileges the solitary life of the sinner disconnected from a social 
context. In his conclusion, Nashe summarizes his "treatise" with a seemingly banal observation - "therefore are the terrors of the night more than of the day, because the sinnes of the night surmount the sinnes of the day"-and an injunction: "hee who in the daye doth not good woorkes inough to answere the obiections of the night, will hardly aunswere at the daye of iudgment" (1:386). This banality appears to undercut the very impulse behind the work, treating the topic as if it were a question already answered, and apparently renders his own writing redundant. But as the concluding gesture of a cycle of works in which Nashe confronts the corruption of his social world, details its multiple manifestations, and presents a model of what divine judgment for these sins might look like, this abrupt ending appears the fitting close for a writer whose creative energy had been spent. It is almost as if, after a long and laborious meditation on sin and judgment from macrocosm to microcosm, Nashe found himself with nothing left to say.

Whether or not Nashe's English readers conceived of interior space as a privileged site in which to experience the interior self, they were certainly encouraged in doing so-by Nashe and other writers of the conscience in the Calvinist vein. These works are then indeed edifying in the sense that they mirrored the serious and sustained attempts by English writers to inculcate in their readers a practical way of navigating the new world of post-Reformation religious thought. Their melancholic tone is a signal device by which writers presented to a literate public a new landscape of sin and judgment, in which the church no longer occupied the centre of the life of faith; instead, the action and belief of the individual occupied a medial zone, determining the health of the nation on the one side and the interior self on the other. Despite the aesthetic blemishes and disagreeableness that have characterized the reception of these tracts for many a modern reader, works like Pierce Penniless, Christ's Tears, and The Terrors merit a special place within the process of transforming the English nation from a formal Protestantism to an internalized Protestant experience. Like the stage when, in learning a foreign language, a speaker begins to think in that language, pamphlets such as these, written in a popular style, provided new elaborations on an essentially stable vocabulary that allowed for its assimilation beyond the rote memorization of orthodox theological principle. Nashe's ability to weave together the language of devotion with popular attitudes speaks to a commensurate ability to charm his audience into registering a spiritual message while delighting in the extemporal method of 
its presentation. These pamphlets reflect and reinforce a confessional posture that included the Calvinist understanding of the conscience as a vital element of a nebulous and transitional conformity. If anything, the print marketplace of late-Elizabethan England provided Nashe with incentives to adopt the language of Calvinist piety that were strictly mercenary.

\section{Notes}

* The author would like to acknowledge the support of the Social Sciences and Humanities Research Council of Canada in the preparation of this research for publication.

1. Thomas Nashe, Works, ed. Ronald B. McKerrow and F. P. Wilson, 5 vols. (Oxford: Basil Blackwell, 1966), vol. 2, p. 208, hereafter cited in the text using volume and page number.

2. Beatrice Groves, "Laughter in the Time of Plague: A Context for the Unstable Style in Nashe's Christ's Tears Over Jerusalem," Studies in Philology 108, no. 2 (Spring 2011), pp. 238-60.

3. Mary Thomas Crane offers a useful summary of the major works inaugurating this association between architecture, interior space, and the private constitution of individuality, first in history and then in literary study. In history, see Lawrence Stone's The Family, Sex, and Marriage in England, 1500-1800 (New York: Harper, 1979), Mark Girouard's Life in the English Country House (New Haven: Yale University Press, 1978), and Alice Friedman's House and Household in Elizabethan England: Wollaton Hall and the Willoughby Family (Chicago: University of Chicago Press, 1988). In literary criticism, a select list includes Patricia Fumerton, Cultural Aesthetics: Renaissance Literature and the Practice of Social Ornament (Chicago: University of Chicago Press, 1991); Richard Rambuss, "The Secretary's Study: The Secret Design of The Shepheardes Calendar," ELH 59, no. 2 (1992), pp. 313-35; and Alan Stewart, Close Readers: Humanism and Sodomy in Early Modern England (Princeton: Princeton University Press, 1997). See Mary Thomas Crane, "Illicit Privacy and Outdoor Spaces in Early Modern England," Journal for Early Modern Cultural Studies 4, no. 1 (Spring/Summer 2009), pp. 4-22.

4. Lawrence Stone, Lena Orlin (see Orlin's Locating Privacy in Tudor London [Oxford: Oxford University Press, 2004]), and others acknowledge the limits of indoor 
privacy, continually subverted by servants, the difficulty of buffering sound, and the presence of holes in many walls. See Crane, pp. 4-5.

5. Crane notes how outdoor spaces function as privileged sites for solitude and seclusion in an array of early modern texts, noting how "illicit sexual activity, excretory functions, treasonous plotting, and gossip are commonly and casually associated with outdoor spaces" (p. 5).

6. Christopher Pye, The Vanishing: Shakespeare, the Subject, and Early Modern Culture (Durham: Duke University Press, 2002).

7. Camille Wells Slights, "Notaries, Sponges, and Looking-Glasses: Conscience in Early Modern England," English Literary Renaissance 28, no. 2 (1998), pp. 231-46, p. 232.

8. In Greenes Groatsworth of Wit, the wealthy merchant tells his sons, "looke but into the dealings of the world, and thou shalt see it is but idle words." Robert Greene, Greenes groats-worth of witte (London, 1592), B3 ${ }^{\mathrm{r}}$. The bulk of the work concerns the conscience and its function in leading the sinner to repentance. See Lori Humphrey Newcomb, “A Looking Glass for Readers: Cheap Print and the Senses of Repentance," in Writing Robert Greene: Essays on England's First Notorious Professional Writer, ed. Kirk Melnikoff and Edward Gieskes (Burlington: Ashgate, 2008), pp. 133-56.

9. Debora Kuller Shuger, Habits of Thought in the English Renaissance: Religion, Politics, and the Dominant Culture (Los Angeles: University of California Press, 1990), p. 12.

10. See Groves, and Catherine I. Cox, "Voices of Prophecy and Prayer in Thomas Nashe's Christ's Tears Over Jerusalem," in Renaissance Papers 2000, ed. T. H. Howard-Hill and Philip Rollinson (Rochester: Camden House, 2000), pp. 51-70; and Peter Holbrook, Literature and Degree in Renaissance England (Cranbury: Associated University Presses, 1994).

11. McKerrow, Works, vol. 4, p. 197; vol. 5, p. 23.

12. G. R. Hibbard, Thomas Nashe: A Critical Introduction (London: Routledge and Kegan Paul, 1962), pp. 112-13.

13. C. G. Harlow, "A Source for Nashe's Terrors of the Night, and the Authorship of 1 Henry VI,' Studies in English Literature, 1500-1900 5, no. 1 (Winter 1965), pp. 31-47, p. 44.

14. Charles Nicholl writes that Nashe's "spell" in the country, presumably the time in which The Terrors was written, "seems to have been a decidedly unsettling period," in A Cup of News: The Life of Thomas Nashe (London: Routledge and Kegan 
Paul, 1984), p. 153. The psychological analogy continues in Stephen Hilliard's The Singularity of Thomas Nashe (Lincoln: University of Nebraska Press, 1986), where he suggests that the tone of the work was influenced by Nashe's professional difficulties during the years 1592-93, "a crisis in Nashe's literary career" (pp. 91, 101).

15. Lorna Hutson, Thomas Nashe in Context (Oxford: Clarendon Press, 1989), p. 114.

16. Craig Koslofsky, Evening's Empire: A History of the Night in Early Modern Europe (Cambridge: Cambridge University Press, 2011), pp. 23-28; Koslofsky also places Nashe alongside Norden for their discussions of the night in relation to witchcraft (pp. 41-43).

17. J. W. Saunders observes that the most popular-and profitable-printed works of the Elizabethan period included the Sternhold-Hopkins Psalter (1549) and John Norden's Pensive Man's Practice. See Saunders's “Preface to the Second Edition," in Phoebe Sheavyn, The Literary Profession in the Elizabethan Age, 2nd ed. (Manchester: Manchester University Press, 1967), pp. vii-viii. For more recent and more comprehensive studies of the early modern English print market and the works that dominated it, see Sandra Clark, The Elizabethan Pamphleteers: Popular Moralistic Pamphlets 1580-1640 (London: The Athlone Press, 1983), and Ian Green, Print and Protestantism in Early Modern England (Oxford: Oxford University Press, 2000), each of which includes empirical surveys of surviving extant material. Clark notes, "half of all books extant between 1583 and 1623 were theological" (p. 34).

18. David J. Baker, On Demand: Writing for the Market in Early Modern England (Stanford: Stanford University Press, 2010), p. 39.

19. For Andersen, the pivotal point of the debate between Walsham and Lake consists of whether religious ideas (as Walsham suggests) enter works of cheap print in an "unconscious, collective process of cultural synthesis," which syncretizes and recycles from medieval and folk traditions and waters down any theological message, or whether pamphlets could, as Lake argues, actually have been used "to popularize doctrinal tenets." Both views are certainly thinkable and not mutually exclusive. See Andersen, “Thomas Nashe and Popular Conformity in Late Elizabethan England," Renaissance and Reformation / Renaissance and Réforme 25, no. 4 (2001), pp. 25-43, p. 28. See also Peter Lake, with Michael Questier, The Antichrist's Lewd Hat: Protestants, Papists and Players in Post-Reformation England (New Haven: Yale University Press, 2002) and Alexandra Walsham, Providence in Early Modern England (Oxford: Oxford University Press, 2003). Tessa Watt sees less of a "simple replacement of Catholic with Protestant doctrine, [but] a 
gradual modification of traditional piety"; the ensuing "patchwork of beliefs may be described as distinctively 'post-Reformation,' [but] not thoroughly 'Protestant." See Watt's Cheap Print and Popular Piety 1550-1640 (Cambridge: Cambridge University Press, 1991), p. 327.

20. Brian Cummings, The Literary Culture of the Reformation: Grammar and Grace (Oxford: Oxford University Press, 2002), p. 286.

21. Eamon Duffy, The Stripping of the Altars: Traditional Religion in England 1400-1580 (New Haven: Yale University Press, 1992), p. 570; see also Duffy's The Voices of Morebath: Reformation and Rebellion in an English Village (New Haven: Yale University Press, 2003) and Saints, Sacrilege, and Sedition: Religion and Conflict in the Tudor Reformations (London: Bloomsbury Publishing, 2012).

22. Peter Lake describes Whitgift as "in effect, claiming to be a better Calvinist than his puritan adversaries who made so much of the Genevan example." See Moderate Puritans and the Elizabethan Church (Cambridge: Cambridge University Press, 1982), p. 220.

23. See Alexandra Walsham, Church Papists: Catholicism, Conformity, and Confessional Polemic in Early Modern England (Woodbridge: Boydell Press, 1999), which amounts to a reformulation of the "parish Anglican" advanced by Christopher Haigh in "The Church of England, the Catholics and the People," in The Reign of Elizabeth I, ed. Christopher Haigh (Basingstoke: Palgrave Macmillan, 1984), pp. 214-19.

24. Slights, p. 233.

25. See Randall Zachman, The Assurance of Faith: Conscience in the Theology of Martin Luther and John Calvin (Minneapolis: Fortress Press, 1993), p. 98.

26. Jean Calvin, The institution of Christian religion written in Latine by M. John Calvine, trans. Thomas Norton (1587), vol. 1, ch. 3, sec. 2 / vol. 1, f. $4^{\text {r. }}$ The 1587 reprint of Thomas Norton's 1561 translation is based on Calvin's definitive Latin text of 1559. Calvin's book, chapter, and section numbers are given first, preceding the volume and page number of the 1587 edition.

27. Calvin, vol. 2 , ch. 8 , sec. 1 / vol. 1 , f. $113^{\text {r }}$.

28. Calvin, vol. 3, ch. 19, sec. 15 / vol. 1, f. $280^{\mathrm{v}-\mathrm{r}}$. Slights cites Perkins for a definition of the conscience, and Perkins repeats the essential structure elaborated by Calvin: "both the internal and the external-a private inner voice and the obligatory force of moral law," emphasized in the etymology of the word that combines knowledge with awareness, and the location of the conscience between God and the human individual (see Slights, pp. 232-33). Zachman provides an ample discussion of this 
and related passages in the Institution through which Calvin defines his interpretation of the conscience, including the distinction between knowledge and awareness-scientia and conscientia-and related affective conditions of persecution, trial, self-condemnation, and fear. See Zachman, pp. 98-102, 150-51.

29. The Geneva Bible: A Facsimile of the 1560 Edition (Madison: University of Wisconsin Press, 1969), f. $3^{\mathrm{v}}$ nf, f. $3^{\mathrm{v}}$, f. $3^{\mathrm{v}}$ nl.

30. Calvin, vol. 3 , ch. 4 , sec. 8 / vol. 1 , ff. $205^{\mathrm{r}}-6^{\mathrm{v}}$.

31. John Stachniewski explains that "Calvin himself was England's most published author between 1548 and 1650. From 1574 to 1587, there were fifteen editions of The Institution of the Christian Religion," and from circa 1580 onward the treatise was compulsory material at both Cambridge and Oxford. Ninety editions of Calvin's various works were published by 1600 . See The Persecutory Imagination: English Puritanism and the Literature of Religious Despair (Oxford: Clarendon Press, 1991), p. 17.

32. Green, p. 311.

33. Saunders, pp. vii-viii; see also Mary Hampson Patterson, Domesticating the Reformation: Protestant Best Sellers, Private Devotion, and the Revolution of English Piety (Madison and Teaneck: Fairleigh Dickinson University Press, 2007), p. 202.

34. John Norden, A Pensive Mans Practise Very Profitable for All Personnes (London, 1584), frontispiece.

35. Norden, ff. $3^{\mathrm{r}}-4^{\mathrm{v}}$.

36. As Patterson explains "the Natural world that God rules over is, to Norden, an awe-inspiring, wonderfully terrifying place” (p. 228).

37. Norden, f. $4^{\text {r }}$, f. $8^{\mathrm{v}}$.

38. Norden, ff. $23^{\mathrm{r}}-24^{\mathrm{r}}$.

39. Norden, ff. $24^{\mathrm{r}}-25^{\mathrm{v}}$.

40. Perkins's position within the taxonomy of theological tendencies of the Elizabethan Religious Settlement remains controversial. Patrick Collinson describes Perkins as "the prince of Puritan theologians and the most eagerly read," while at the same time belonging to a "later and more relaxed generation" than predecessors like Thomas Cartwright or the authors of the Marprelate pamphlets. See The Elizabethan Puritan Movement (Berkeley: University of California Press, 1967), p. 125. W. B. Patterson extends this view, emphasizing that Perkins's Calvinist theology and moderate views on ecclesiastical hierarchy essentially functioned as an antidote to more militant calls for ecclesiastical reform. See "William Perkins 
as Apologist for the Church of England," Journal of Ecclesiastical History 57, no. 2 (April 2006), pp. 252-69.

41. Green, p. 647.

42. William Perkins, $A$ treatise tending unto a declaration whether a man be in the estate of damnation or in the estate of grace (London: 1590), p. 176. Although Perkins is markedly more emphatic than Norden regarding the doctrine of predestination, this should not be read as particularly controversial. As Stachniewski observes, "one can say that Calvinist theology (including that of Perkins) was orthodoxy; the call for immediate and large-scale reform of ecclesiastical and political structures was not" (Stachniewski, pp. 12-13).

43. Perkins, p. 59, p. 35.

44. Perkins, pp. 37-38.

45. Perkins, pp. 38-39.

46. Perkins, p. 6; Norden, f. $70^{\text {r }}$.

47. Perkins, pp. 99-100, 261.

48. Perkins, pp. 161-62.

49. Nashe's consistent recourse to moralizing social critique, as much as his skilled personal invective typified in his quarrels with the Harveys, or his miscreant grotesque in The Unfortunate Traveller, constituted appeals to the tastes of the popular reading public. Clark writes, "undeniably there was a strong popular taste for moralizing and for didactic writing, so long as it was not too weighty or demanding" (p. 34).

50. Baker, p. 38.

51. Perkins, p. 241.

52. Cox, p. 52, p. 55, citing Nashe (2:16). Christ's Tears is also a noteworthy example of how more serious and studious theological and sermon literature was adapted by popular writers for less cultivated members of the literate and semi-literate public. McKerrow notes that John Stockwood's Sermon of the most Lamentable Destruction of Jerusalem (1584) "in its general plan and line of arguments... very closely resembles Christs Teares"; see Works, vol. 4, p. 213; E. D. Mackerness agrees, albeit by noting that Stockwood's sermon falls within a prophetic tradition she describes as a "literature of warning"; see "'Christs Teares' and the Literature of Warning," English Studies 33 (1952), pp. 251-54. The basic narrative was similarly spun off into an anonymous ballad of the same name, which likely emerged after Nashe's text appeared in print in 1593. Watt surmises that either the ballad version 
descended directly from Nashe's pamphlet or that both authors relied on the same source material; see Watt, p. 98.

53. These parallel Norden's gestures to both divine judgment as the cause of plague and prodigious signs of forewarning; see Norden, f. $69^{\mathrm{r}}$, f. $74^{\mathrm{r}}$.

54. See Cox, p. 55.

55. Hibbard correctly observes an undercurrent to The Terrors that constitutes "an attack on superstition and credulity" (Hibbard, p. 113), conforming not only to the skepticism of Reginald Scot, but also to the predilections of prominent clergy such as George Gifford, Gervase Babington, and William Perkins himself, as they all attacked superstitious beliefs on theological grounds (Walsham, p. 179). For the antagonism of the mainstream clergy towards popular superstition, see Walsham, p. 28 .

56. Harlow shows how the essence of this passage is likely derived from Henry Howard's Defensative, and Nashe's borrowings are indeed too numerous to be listed here. However, it is clear that Nashe's phrasing also refers to the vocabulary elaborated by writers such as Norden and Perkins, beyond that previously employed by Nashe himself, in works such as Christ's Tears. See Harlow, pp. 32-44.

57. Calvin, vol. 1 , ch. 3 , sec. 2 / vol. 1 , f. 4 r .

58. Quoted in Harlow, p. 36.

59. Norden, ff. 54r-56v.

60. Perkins, pp. 7, 43. 